\title{
Analysis Determinants of Investment, Demand, and Supply Indonesian Tourism
}

\author{
Santi, Faurani ${ }^{1}$. Oktarina, R. Budiman H. Dedi ${ }^{2}$. Kustiari, $\mathrm{R}^{3}$
}

\begin{abstract}
Tourism is one of the most significant contributors to the Indonesia growth of economy, based on data from the Indonesia Central Bureau of Statistics in 2012, the share of national tourism to GDP is 13.9 percent and of course the contribution of the sector to be helpful for the growth of the national economy, through foreign exchange earnings as revenue from tourist consumption. Besides that, it has provided a multiplier effect to other sectors which related to the sectors. Therefore, the increasing of tourism investment and trade will be focus in the tourism development program to improve the contribution. Meanwhile, the Indonesia Coordinating Board (BKPM) stated the average national investment for the tourism sector is Rp. 2.73 billion or 6 percent from total investment during 2006-2012, in other words an investment in tourism sector has not been able to provide optimal contribution to the national economy development considering to its potential. The purpose of this study was to analyze the determinants of investment, demand and supply of Indonesian tourism sector. Regarding to answer the problems, this research used series data from 1990 - 2012 periods; by using simultaneous model (2SLS) the model analyzed impact of investment, and international trade of Indonesia tourism sector to the national economic growth. Based on the Two Stages Least Squares method on simultaneous model, the results of the analysis gives some conclusions including: (1) tourism arrivals, tourism expenditure, investment, consumption price index, total consumption, government spending, export and import tourism affected the national tourism demand, (2) Current investment and investment on previous year, total consumption on previous year, and travel warning have positive impact to national tourism supply, (3) GDP was the most influenced variable beside Indonesia tourism price and neighbor countries' tourism price as competitors of Indonesia tourism. Finally, the simulations showed the fiscal and monetary policy impact to the national economic tourism sector.
\end{abstract}

Keyword: Impact, investment, international trade, supply and demand tourism, and economic growth

\section{Introduction}

Tourism is one sector of the Indonesia economy that contributed greatly to the economic development of country, based on data from the Indonesia Central Bureau of Statistics in 2012 the national tourism share of 13.9 percent of the total gross domestic product and of course the contribution of the sector to be useful for the growth of the national economy, through foreign exchange earnings received from the large consumption incurred by the traveler to national goods and services. It is also able to provide a multiplier effect of tourism to other sectors related either directly or indirectly ( Reuters , 1999). As a country that has considerable potential for tourism , Indonesia also has enough potential to gain share in the world tourism market, it is evident based on BPS RI in 2012 there was an increase of 5.8 percent compared with the year 2011 , the amount of foreign exchange earned by 8,6 million tourists, an increase of 13.6 percent compared to the previous period . Associated with government efforts to increase the contribution of tourism and economic growth while improving the welfare of society, then the increase in tourism investment is also the center of attention in the development program, thus the goal for the investment activities are able to increase production. Data Investment Coordinating Board explained that the average investment for the tourism sector is Rp . 2.73 billion during the period 2006-2012 with an average investment made by domestic investment of Rp . 235 Billion and is carried by the PMA average of Rp . 2.45 billion during the period 2006-2012, this figure also shows that the contribution of tourism investment to total investment amounted to only 6 percent (Kemenpraf , 2012 ), in other words, an investment in the tourism sector has not been able to provide optimal contribution to the national economy, although the sector the potential in contributing to the national economy.

Based on the problems, it may be submitted in several investigations at issue as follows : ( 1 ) What factors are affecting investment and tourism trade in goods and services ( trade, hotels and restaurants ), ( 2 ) how the flow of investment and goods and services of international tourism to Indonesia, ( 3 ) how the international tourism demand and supply affects investment and national tourism goods and services, ( 4 ) the factors that influence the demand and supply of tourism in Indonesia, and ( 5 ) whether the investment and trade in goods and services affecting international tourism demand and supply of tourism in Indonesia

\footnotetext{
${ }^{1}$ Faculty of Economics, Parahyangan University, Bandung, West Java, Indonesia

${ }^{2}$ Faculty of Economics and Management, Economics ScienceDepatment, Bogor Agriculture University, Bogor, Indonesia

${ }^{3}$ PSEKP, Indonesia Ministry of Agriculture, Bogor, Indonesia
} 
Therefore, this study aims to : ( 1) to analyze the factors that affect the flow of investment and trade in goods and tourism services ( trade, hotels, and restaurants ) in Indonesia, ( 2 ) identify the influence of international tourism demand and supply of the investment and trade in goods and services in the Indonesian tourism , ( 3 ) analyze the factors that affect the demand and supply of Indonesian tourism ASEAN countries , Japan , USA , Europe, Australia, and the country laainnya ( Rest of the world), and ( 4 ) formulating development policy implications of the tourism sector to increase economic growth.

\section{1 . Identification , Estimation , and Validation of Gravity Models}

In this study, models of investment and trade flows ( exports and imports ) of goods and services created by tourism panel using gravity, with the help of Eviews 7.1 program to perform data processing . Based on 5 models were constructed of the obtained equation is generally used method is the method of Fixed Effect Model Method for Indonesian tourism investment flow model of the flow of goods and services exports of Indonesian tourism, models the flow of imports of goods and services of tourism in Indonesia, and the Indonesian tourism demand flow model, while in the Indonesian tourism flow model supplys a method used is the method of Random Effect ; wherein in determining which method is used ( Fixed Effect of method and Radom Effect ) whereas the F test used in the next stage to determine the method or methods of approach between Fixed Effect and Poole and pooled Least Squared it is used Chow test (Gujaratti, 1995 ). While the test if there is any autocorrelation in the model is built, then used Durbin Watson Test ( DW Test ). In addition , the validity of the model using indicator R2 of each equation .

The models are:

1. Flow of Indonesia Tourism Investment

$$
\operatorname{Ln}(F D I)_{i j t}=+\beta_{1} \operatorname{LnGDP_{it}}+\beta_{2} \operatorname{LnGDP_{jt}}+\beta_{3} \operatorname{LnPOP_{jt}}+\beta_{4} \operatorname{LnPRICE_{ijt}}+\beta_{4} \operatorname{Ln} D I S T_{i j t}+\varepsilon_{i j}
$$

2. Flow of Indonesia Tourism Export

$$
\begin{aligned}
& L_{n} X_{i j t}=\beta_{0}+\beta_{1} \operatorname{LnDIST}_{i j}+\beta_{2} \operatorname{LnGDP} P_{j t}+\beta_{3} \operatorname{LnPOP} P_{j t} \\
& +\beta_{4} \operatorname{LnEXCH}_{i j t}+\beta_{5} \text { LnPrice }_{i j t}+\beta_{6} \operatorname{Ln} X_{i j-1}+\varepsilon_{i}
\end{aligned}
$$

3. Flow of Indonesia Tourism Import

$$
L_{n} M_{i j t}=\beta_{0}+\beta_{1} \operatorname{LnDIST}_{i j}+\beta_{2} \operatorname{LnGDP}_{i t}+\beta_{3} \operatorname{LnEXCH}_{i j t}
$$

$+\beta_{5}$ LnPrice $_{i j t}+\beta_{6} \operatorname{LnM}_{i j-1}+\varepsilon_{i}$

4. Flow of Indonesia Tourism Demand

$$
\begin{aligned}
& \operatorname{Ln}(T R)_{i j t}=\beta_{0}+\beta_{1} \operatorname{LnGDP} P_{i t}+\beta_{2} \operatorname{LnGDP}_{j \mathrm{t}}+\beta_{3} \text { LnPrice }_{i j t}+\beta_{4} \text { Price }_{k j t} \\
& +\beta_{5} \operatorname{LnEXCH}_{i j t}+\beta_{6} \operatorname{LnPOP_{ij}}+\beta_{6} \operatorname{LnTr} C_{i j t}+\varepsilon_{i j}
\end{aligned}
$$

5. Flow of Indonesia Tourism Supply

$$
\begin{aligned}
& \operatorname{LnTS}_{i j}=\beta 0+\beta 1 \operatorname{LnGDP_{it}}+\beta 2 \operatorname{LnGDP} P_{j t}+\beta 3 \operatorname{LnDistance}_{i j t}+\beta 4 \operatorname{LnPrice} \text { Pijt }_{i}+\beta 5 \operatorname{LnEXCH_{ijt}} \\
& +\beta 6 \operatorname{Ln} C_{i t}+\beta 8 \operatorname{LnPop} p_{i j}+\beta 9 \operatorname{LnD} 1_{i}+\beta 10 \operatorname{LnD} 2_{i}+\beta 11 \operatorname{LnD} 2_{j}+\varepsilon_{i j}
\end{aligned}
$$

\section{2 . Identification, Estimation, and Simultaneous Model Validation}

In this study, there are two blocks of equations that Indonesian tourism demand equation block, and the block supplys Indonesian tourism . While the identification of over-identified equation shows all the used methods Two Stage Least Squares ( 2SLS ), economic models additives include 11 linear equations ( equations 9 and 2 structural equation identity). Research includes 57 variables ( current endogenous variables 15,8 current exogenous variables, and 11 bedakala exogenous variables ). Data processing program SAS / ETS version 9.1 . F-test to examine the relationship between variables simultaneously, while the t-test to examine the relationship between the individual and the endogenous explanatory variables. DW test for the identification of the symptoms of autocorrelation. Dw test for simultaneous equations with lag endogenous variables ( lagged - endogenous variables ). Validation criteria or either / or absence of the alleged value of econometric models is the Root Mean Square Error ( RMSE), Root Mean Square Percentage Error ( RMSPE) and U - Theil coefficient . In addition, the validity of the model using indicator R2 of each equation. While to investigate the impact of supply and demand effects of international tourism to investment and trade in goods and services of tourism in Indonesia, then used some of the analysis : ( 1 ) GDP GDP rising home countries of foreign tourists amounted to 3 percent, ( 2 ) interest rate of 5.75 percent, ( 3 ) Inflation amounted to 6.8 per cent due to higher prices of subsidized fuel, ( 4 ) the magnitude of the consumption increase by 10 percent due to the economic growth of 6 percent per year, ( 5 ) the fall in investment by 10 percent, , 6 ) decrease in the number of tourist arrivals by 10 percent due to the travel warning, and ( 7 ) the depreciation of the domestic currency against foreign currencies by 10 percent. 
The models are:

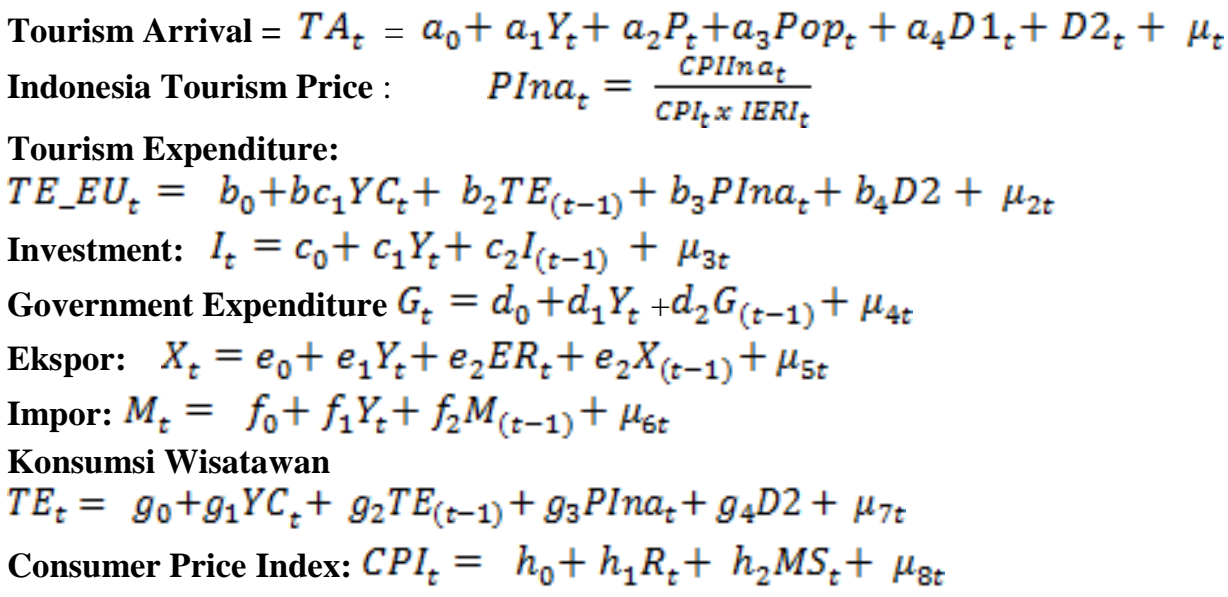

\subsection{Flow of Indonesia Tourism Investment}

\section{Analysis And Results}

$\mathrm{f}$ the function of direct investment flows ( FDI ) from ASEAN countries ( Malaysia , Singapore , Thailand, and Filipna ), Japan, United States, European Union, Australia, and Rest of the World ( ROW ) to Indonesia, which describes the relationship between the magnitude of investment coming from the country of origin of foreign tourists to Indonesia ( in this case is Foreign Direct Investment ) of the independent variable GDP ( tourist home countries and Indonesia), the number of population ( travelers home country ), Price Tourism ( tourist home countries and Indonesia), and the distance ( between travelers and Indonesian origin ) as a proxy. Influence the magnitude of investment flows into Indonesia tourism to GDP is positive country of origin of tourists, this means that an increase in investment ( inward ) Indonesian tourism GDP will increase for both parties ( Indonesia and the country of origin of tourists ) over a period of 23 years the amount of investment ( inward ) Indonesia from other countries as a whole in 2012 was 1.9 billion USD, up by 18 percent compared to 2011 . While the influence of investment to the country of origin population of tourists and the distance between the country of origin of foreign tourists to Indonesia is positive and significant, indicating that the value of investments ( inward ) which produced the two variables in the sense that if the direction of origin of foreign tourists rising population is increasing the amount of investment ( inward ) generated also increases . Neither the distance, the closer the distance between Indonesia and countries of origin of tourists, the greater the value of the resulting investment (Archer, Brian \& Cooper . 1994). As in the case of Singapore investment tends to increase, in addition to the trend factor increase in GDP of the country for a period, which is close to the distance Singapore Indonesia was the determining factor in generating investment ( inward ).

\subsection{Flow of Indonesia Tourism Goods and Services Exports}

In this method a variable distance, price of Indonesian tourism homestead in the country of origin, the exchange rate against foreign currencies origin of tourists, population, tourism and exports of the previous year is a variable that significantly influence the 95 percent confidence level, which indicates the effect of the distance to the positively to the value of exports of goods and services is tourism means to the increasing distance between the country of origin of foreign tourists visiting Indonesia to raise the value of exports of goods and services of Indonesian tourism. While the relationship between the value of exports of goods and services at a price of Indonesian tourism Indonesian tourism in the countries of origin of tourists and the exchange rate to the amount of tourism exports is negative, the fall of the domestic currency against foreign currencies led to the goods originating from abroad ( imports) will be more expensive than the goods in the country, and it also led to an increase in exports, on the other hand a direct relationship ( positive ) occurs in a population and tourism exports in the previous year. Overall the estimation results obtained from the relationship antaara export value of tourism to the explanatory variables is equal to 92.7 percent .

\subsection{Flow of Indonesian Tourism goods and services Imports}

At this import flow method variable distance, Indonesian GDP, and imports of goods and services in the previous year Indonesian tourism is a variable that significantly ( at the 99 percent confidence level ) . Relationship between the value of imports of goods and services to the tourism tourism prices expressed in a negative relationship in the estimation results, according Made Suyana (2006), the increasing growth of tourism sector in the tourist area will always be followed by a rise in consumption is needed, if those needs are not able to offset the domestic production capacity generally those needs will be met with efforts to import the goods and services needed by the tourism actors. Also, the estimation results obtained from the positive 
relationship between the import value of imports of goods Tourism with tourism services earlier this year means that the increase in the value of imports of the previous year will be followed by a rise in the years thereafter and vice versa. In general, the statistical results obtained from the relationship between the value of imports of goods and services to the Indonesian tourism is the independent variable by 96 percent and the remaining 4 percent are influenced by factors other than the study of factors such as tariff, which tariff component itself during nearly 10 decades since the entry of Indonesia to be a member of the World Trade Organization forum , components tend to rate the wane, and this of course indicates that, with the agreement of the reduction and elimination of some tariffs for some goods and services allows for easy going flow of goods and services that enter to Indonesia ( Widjaja, 2000).

\subsection{Flow of Indonesia Tourism Demand Goods and Services}

In the flow model of the tourism demand variable Indonesian GDP, GDP countries of origin of tourists , the price of Indonesian tourism, tourism price of other countries, and tourism consumption , are variables that significantly affect demand for Indonesian tourism at 90 percent confidence level with 93.2 percent of the relationship, where all explanatory variables thinking about relationships that are positive except the Indonesian tourism price variable that is negative to the amount of demand for Indonesian tourism . Positive relationship indicates that if the variable GDP, price tourism competitor countries ( other countries ), and consumption of tourism, the number of requests increases, increase tourism, the coefficient for the change . Phenomenon empirically shows that the increase in GDP shows the increase in production and income levels in a country as a whole, increased production directly trigger an increase in income so that consumption will increase in line with rising incomes. Conditions where GDP has increased (in 2012 rose 5 percent ) of course become a basis for economic growth in various sectors including the tourism sector, as well as the GDP of countries of origin of tourists, though to European Union countries which for several years was since the economic crisis hit Europe GDP growth for the countries in the region showed a negative trend but this does not really affect the magnitude of Indonesian tourism demand, as well as Australia where the GDP in 2012 rose by 2.5 percent dibandikan with the previous year. Australian GDP upward trend also shows an increase in tourism demand indicating the economic growth is increasing the level of social welfare due to the increase in revenue earned so with the increase in the end come to raise the overall consumption. While the positive relationship between the price of tourism with other countries shows that Indonesia's tourism demand with rising prices in other countries tourism is an opportunity for Indonesia to take the opportunity to increase the number of tourists, including in this case the demand for goods and services needed in tourism (Adi Laksono , 2011). Because basically the international tourism demand in Indonesia is influenced by the country of origin of tourist income , price of Indonesian tourism, and tourism price competitor countries, in this study is Malaysia , Singapore, and Thailand, and whether tourist arrivals to Indonesia is a series of three traveling tourism the country ( as complements ) or a single choice as a premier travel destination ( as substitutes ). Price of tourism actually consists of prices of various types of goods and services making it difficult to get a single number on the price , therefore, the price of tourism can be represented by the destination country 's consumer price index divided by the consumer price index divided by the travelers home country currency exchange rate to two countries ( Choyakh , 2008).

\subsection{Flow of Indonesian Tourism Supply}

From the estimation, it is evident that 5 variables that significantly influence the magnitude of Indonesian tourism supplyings : Indonesian GDP , price of Indonesian tourism, consumption Indonesia, and dummy economic crisis in Indonesia. Relationship between the magnitude of the consumption of tourism supplyings Indonesia Indonesia tourism which is positive in all countries where the average has increased by 5 percent with the production capacity is expressed by the amount of capacity -star hotels and other accommodation is no less than 0.5 million hotel beds, exactly 542.640 points sleeping with details of 191.948 star hotels and other accommodation bed bed number 350.692 ( BPS , 2012), is contrary to the conditions that really happened, where the ability of the tourism production capacity in the year 2011 the number of foreign tourist arrivals recorded BPS Indonesia increase 10 percent compared to the previous year, this is due to the reduction in the amount of consumption by other countries due to a slowdown in economic growth in the world ( especially the United States, and European countries ) which has decreased an average of 3.5 percent in 2011 ( IMF , 2012). While the relationship between the magnitude of Indonesian tourism deals with the amount of national income is positive indicates that the magnitude of the increase Indonesia's GDP increase tourism supplyings, the stated amount of tourism supplys the ability of tourism production capacity on the one hand is the government spending to fund efforts to increase the production capacity, this means with the increasing national income will encourage production activities are followed with the increasing supplys in various sectors including tourism. While the rising price ratio between Indonesia tourism in other countries shows that there has been a rise in prices of tourism caused by rising costs of production inputs. Inflation supplys also include 
supply shocks that could trigger inflation price increases the supply of goods ( Samuelson and Nordhaus , 2004) . Factor shock ( shock) are included in this inflation is when there is an increase in international commodity prices including crude oil prices, rising food prices due to production shock caused climate disruption and weather, or the rise in import prices due to the depreciation of the exchange rate, it this also applies to increasing domestic consumption will lead to an increase in the prices of goods in the domestic rupiah depreciated even more so if the impact on the cost of production using imported components . In contrast to the negative relationship is the tourism supply in the variable exchange rate against foreign currencies and the economic crisis dummy Indonesia, this happens because in a crisis rupiah depreciated against foreign currencies as a result of production costs in the country, will increase production costs incurred primarily by industries that use imported material component. Conversely in times of crisis that the rupiah depreciated against foreign currencies led to price ratio of the price of domestic goods in other countries declined as a result of domestic prices including the price of tourism is much cheaper than the price of tourism in other countries and this is what triggered the increase in foreign tourist arrivals to Indonesia.

\subsection{Indonesia Tourism Demand Analysis}

From the results obtained that estimates the magnitude of the relationship between the nine endogenous variables ( visits by foreign tourists, expenditure by foreign tourists, Tourism Investment , for Tourism, Government spending in the tourism sector, tourism exports, and imports of tourism ) with exogenous variables derived from 6 countries ( ASEAN, Japan, USA, Europe, Asutralia, and the whole world ) to block the demand ranges from 25 percent to 99 percent .

The above table of results can be explained on the impact of each vairabel exogenous to endogenous variables as follows :

1. The impact of an increase in the number of foreign tourists visiting the inflation rate is essentially not directly ( through the exchange rate transmission ), and with the exchange rate changes ( both appreciation and depreciation of currencies ) will affect revenues, which in turn affects the level of consumption as measured by the ability of purchasing. Vice versa, the increase in the purchasing power of the domestic currency will be followed by a proportional appreciation of its currency, as such, changes in currency exchange rates of a country or due to the occurrence and causes of inflation in the country (Singh ,1997), so that the changes in exchange rates between countries sending and receiving travelers affect tourism receipts which triggered inflation due to an increase in purchasing power due to the increase in revenue .

2 . Conditions under which a country 's economic crisis is usually marked by slow economic growth in which an increase in inflation and the exchange rate depreciating currency, a condition in which the domestic currency depreciates then the prices of goods in the country will be much cheaper and in this condition it is also a competitiveness of the country will experience at a better price to the prices in other countries and of course will affect the demand ( Dornbusch, et.al ; 2004) . In the case of Indonesian tourism demand impact of Asean and Japan to demonstrate the economic crisis dummy with the economic crisis will raise ASEAN tourism investment in Indonesia, this phenomenon shows that despite the economic crisis, but does not affect the investment climate in Indonesia, as Indonesia is one of the countries that have a huge potential and broad among Asean countries, it is the primary attraction for other countries including ASEAN countries ( both Singapore and Malaysia as the largest Asean investor in Indonesia). While at the time of economic crisis characterized by negative economic growth, one of the efforts to revive the economy by increasing government consumption dalah where the increase in consumption is expected to meciptakan growth factors of production in the country that can boost employment and incomes (Between, 1999). In contrast to the results estimated in some countries ( Europe, USA, Autralia, and ROW ) which indicates that the loan interest rate in a country is negatively related to the level of high investasi.Semakin interest rate, the lower the level of investment, and vice versa because the interest rate is cost of capital that must be removed . In other words, the higher the interest rate it charges to be incurred ( Cost of Capital ) issued also greater ( Horvart , 2006)

3 . Conditions where the higher the national income of a country, the higher the demand for goods - imported goods. This is because in a country that experienced an increase in income tends to strengthen the exchange rate , in which the exchange rate changes on output growth seen large effect on the economy is open. If the exchange rate tends to strengthen the country could lead to an increase in imports as prices of imported goods will be cheaper than the entry price in the country, thus, decrease the value of its own currency exchange rate tends to increase net exports, and vice versa .

4 . Variable impact on the level of the consumer price index in the tourism consumption Indonesia_Jepang tourism demand model indicates that under conditions of price increase on certain items will affect the prices of other goods including tourism will lead to inflation as well as rising transportation costs due to rising prices fuel which in turn will raise the prices of other goods and services, including commodity prices used in tourism activities . In other words, the growing conditions where total demand will trigger changes in the price level ( demand pull inflation ), this happens because of the increasing volume of medium of exchange or liquidity 
associated with the demand for goods and services resulting in increased demand for factors of production ( Dornbusch et . al ; 2004) .

5 . Income on variable parameter estimation shows that with an increase in the value of exports by 1 percent tourism will increase revenue peubahnya coefficient, an increase in a country's exports show has been an increase in the production sectors in the country so affected people's income increase due to the increasing factor - factor production in the country ( Sadono Sukirno , 2001). While exports lagged variable parameter estimates indicate that the previous year with an increase in the value of exports by 1 percent in the previous year will be followed by increase in export value of the coefficient peubahnya increase for next year .

6 . The impact of income per capita consumption of foreign tourists to variable ; course with rising per capita income will affect people's purchasing power as well as the ability to consume. So is the increase in price of Indonesian tourism in the countries of origin of tourists would affect the competitiveness of Indonesian tourism competitiveness means, if the declining competitiveness of Indonesian tourism price is considered expensive and of course will affect the amount of consumption that was issued, because basically the price increase tourism triggered by the presence of ter - inflation or currency appreciation dometik ( IDR ) against foreign currencies, triggering a rise in prices in the country (Singh, 1997). Whereas if the impact of consumption to economic crisis dummy variable is negative then it would indicate the onset of decline in the consumption trend of tourists due to the economic crisis and this will also affect inflation and the exchange rate, because at the time of the economic crisis the purchasing power of which tend to decrease .

7 . Effects of inflation ( CPI ) to variable interest rates and money supply in the country in several countries, showed that with the increase in the domestic money penawana by 1 percent would raise the amount of CPI ( inflation ) of coefficients peubahnya, which deals with the amount of money in society will trigger the growing circulation of money in the community that will lead to increased demand which in turn led to an increase in prices ( inflation ).

8 . Travel warning against the impact dummy endogenous variable consumption and foreign tourists visiting the estimation results shown in block - European demand for Indonesian tourism, where the results showed that with the travel warning for Indonesia tourism which is shown by the prospective tourists will impact than the number of foreign tourists of course it will directly affect the amount of consumption incurred by tourists themselves, which in turn of course will have a negative impact on revenues from tourism for Indonesia .

3.7. Analysis of Tourism Expenditure (Supply)

Block of Indonesian tourism supply, in this study used three structural equation models are equations consumption of goods and tourism services (CT_Ina), investment and capital formation Indonesian tourism (IT_Ina), and government spending in the tourism sector, Indonesia (GT_Ina) . Model equations consumption of goods and services of Indonesian tourism, which obtained the overall magnitude of the coefficient of determination ( $\mathrm{r}$ - square ) 0.516 which shows that the variation of the relationship between the explanatory variables on the endogenous variable is equal to 51.6 percent, where the variable lag consumption on a year earlier, and visits foreign tourists to Indonesia are all factors that affect the most dominant in the Indonesian tourism consumption . Relationship between investment, government spending, and consumption of tourism on tourism investment is positive, according to Keynes stated that with the increase in investment is usually followed by a rise in consumption and government spending, ceterus paribus, and this is empirically proven in this case ( Dornbusch et . al ; 2004). The model equations are all within a block of two Indonesian tourism supply is the model equation and the formation of capital investment in Indonesia's tourism sector, which in this model is obtained coefficient of determination ( $\mathrm{r}$ - square ) of 0.977 . While the factors that influence the tourism sector investment variables Indonesia is Indonesia's GDP, investment in the previous year, and spending pememrintah . If it is known that the investsi tourism is a type of short-term investments which, according to Adrian Bull ( 1995 ) most of the tourism investment mmerupakan type of activity with periods of short-term investment returns (payback period) is relatively short. On government spending equation model in the tourism sector, based on the results lag estimates of government spending in the previous year, the large number of foreign tourists visiting, and the large number of foreign tourists visit in the previous year are the dominant factors that affect government spending in the tourism sector, with the magnitude of the relationship is 60.5 percent. 


\section{Tables}

4.1. Flow of Investment, Trade, Supply and Demand in Tourism Sector

\begin{tabular}{|c|c|c|c|c|c|}
\hline \multicolumn{3}{|c|}{ Flow of Investment Tourism } & \multicolumn{3}{|c|}{ Flow of Tourism Import } \\
\hline Variable & Elastisitas & Prob. & Variabel & Elastisitas & Prob. \\
\hline GDPJT & 0.21512 & 0.1414 & DISTIJT & -1.595 .408 & 0.0000 \\
\hline POPJT & 0.748571 & 0.0000 & GDPIT & 1.939 .836 & 0.0000 \\
\hline DISTIJT & 0.66006 & 0.0006 & MIJT_1 & 0.08703 & 0.0000 \\
\hline R_Squared & \multicolumn{2}{|c|}{0.422062} & R-squared & \multicolumn{2}{|c|}{0.960388} \\
\hline F_Stat & \multicolumn{2}{|c|}{1.927 .966} & F-statistik & \multicolumn{2}{|c|}{3.079 .121} \\
\hline DW & \multicolumn{2}{|c|}{1.739 .132} & DW & \multicolumn{2}{|c|}{1.290 .127} \\
\hline \multicolumn{3}{|c|}{ Flow of Tourism Export } & \multicolumn{3}{|c|}{ Flow of Tourism Demand } \\
\hline Variabel & Elastisitas & Prob. & Variabel & Elastisitas & Prob. \\
\hline DISTIJT & 0.182092 & 0.0040 & GDPIT & 0.147952 & 0.0086 \\
\hline POPJT & 254.226 & 0.0058 & GDPIJT & 0.268073 & 0.0097 \\
\hline EXCHIJT & -0.364769 & 0.1265 & PRICEIJT & 0.229171 & 0.0658 \\
\hline PRICEIJT & -0.364744 & 0.0035 & PRICEKJT & $-0,764109$ & 0.0297 \\
\hline XIJT_1 & 0.099236 & 0.0000 & POPIJT & $-0,43152$ & 0.1592 \\
\hline $\mathrm{R}$-squared & \multicolumn{2}{|c|}{0.927824} & TRCIJT & 0.094417 & 0.0003 \\
\hline F-statistik & \multicolumn{2}{|c|}{1.472 .474} & $\mathrm{R}$-squared & \multicolumn{2}{|c|}{0.932485} \\
\hline $\begin{array}{r}\text { Durbin- } \\
\text { Watson stat }\end{array}$ & \multicolumn{2}{|c|}{1.139 .904} & F-statistik & \multicolumn{2}{|c|}{1.438 .709} \\
\hline \multicolumn{3}{|c|}{ Flow of Tourism Supply } & $\begin{array}{l}\text { Durbin-Watson } \\
\text { stat }\end{array}$ & \multicolumn{2}{|c|}{11.780 .093} \\
\hline Variabel & Elastisitas & Prob. & & & \\
\hline GDPIT & 0.582309 & 0.0008 & & & \\
\hline PRICEIJT & 1.104 .903 & 0.0000 & & & \\
\hline EXCHIJT & -107.399 & 0.0001 & & & \\
\hline CIT & 0.449388 & 0.0610 & & & \\
\hline DIJT & $-0,11603$ & 0.0411 & & & \\
\hline $\mathrm{R}$-squared & \multicolumn{2}{|c|}{0.956654} & & & \\
\hline F-statistik & \multicolumn{2}{|c|}{179.504} & & & \\
\hline $\begin{array}{c}\text { Durbin- } \\
\text { Watson stat }\end{array}$ & \multicolumn{2}{|c|}{1.095 .302} & & & \\
\hline
\end{tabular}

4.2. Block Indonesia Tourism Supply Results Estimation:

\begin{tabular}{|c|c|c|c|}
\hline \multicolumn{4}{|c|}{ Indonesia Tourism Supply } \\
\hline \multicolumn{4}{|c|}{ Tourism Consumption (CT_Ina) } \\
\hline Variable & $\begin{array}{r}\text { Parameter } \\
\text { Estimasi }\end{array}$ & R-Squared & $\mathbf{F}$ \\
\hline LCT_Ina** & 0.589698 & 0.51649 & 2.67 \\
\hline TA_Ina $a^{* \cdots}$ & 532.488 & & \\
\hline \multicolumn{4}{|c|}{ Tourism Investment (IT_Ina) } \\
\hline Y_Ina* & 1.235 .293 & \multirow[t]{3}{*}{0.97718} & \multirow[t]{3}{*}{85.64} \\
\hline LIT_Ina $a^{* \star}$ & -0.13757 & & \\
\hline GT_Ina* & 102.918 & & \\
\hline \multicolumn{4}{|c|}{ Government Expenditure in Tourism Sector (GT_Ina } \\
\hline LGT_Ina* & 0.799226 & \multirow[t]{3}{*}{0.60566} & \multirow[t]{3}{*}{4.91} \\
\hline TA_Ina**i & 446.632 & & \\
\hline LTA_Ina $\approx * *$ & 382921.2 & & \\
\hline
\end{tabular}




\subsection{Block Tourism Demand Estimation Results}

\begin{tabular}{|c|c|c|c|c|c|c|c|c|c|c|c|}
\hline \multicolumn{4}{|c|}{ ASEAN5+ } & \multicolumn{4}{|c|}{ Jepang } & \multicolumn{4}{|c|}{ FU } \\
\hline Variable & \begin{tabular}{l|} 
Parameter \\
Estimation
\end{tabular} & R-squared & $\mathbf{F}$ & Variable & \begin{tabular}{l|} 
Parameter \\
Estimation
\end{tabular} & R-Squared & $\mathbf{F}$ & Variable & \begin{tabular}{|l|}
$\begin{array}{l}\text { Parameter } \\
\text { Estimated }\end{array}$ \\
\end{tabular} & R-Squared & $\mathbf{F}$ \\
\hline \multicolumn{4}{|c|}{ Tourism Arrival Asean (TA_Asean5 + ) } & \multicolumn{4}{|c|}{ Tourism Arrival (TA_JPN) } & \multicolumn{4}{|c|}{ Tourism Arrival (TA_EU) } \\
\hline PINA_ASEAN5 $+* \star *$ & $-4453,13$ & 0,59111 & 2,89 & CPI_JPN*** & 41681,4 & 0,59253 & 4,65 & Y_EU $U^{* *}$ & \begin{tabular}{|r|}
$-0,01073$ \\
\end{tabular} & 0,85058 & \\
\hline ER_Asean5+** & \begin{tabular}{|l|}
$-3838,15$ \\
\end{tabular} & & & D2***** & \begin{tabular}{|l|}
79300,6 \\
\end{tabular} & & & $\mathrm{Dl}^{* * *}$ & 22,7481 & & \\
\hline & & & & & & & & $D^{2 * \star \star \star *}$ & $-22,6332$ & & 14,23 \\
\hline Tourism & cpenditure (TE & Asean5+) & & Tour & Expenditure & (IE_JPN) & & Tour & rism Expenditure & e(TE_EU) & \\
\hline$\overline{\text { YC_Asean5+*** }}$ & 56,23635 & & 6,54 & YC_JPN** & 66,86552 & & & YC_EU & 7,450054 & & 6,12 \\
\hline PLNA_ASEAN5+** & 270,4463 & & & PINA_JPN $* * *$ & $-78363,9$ & & & LTE_EU ${ }^{* *}$ & 0,477858 & & \\
\hline ER_Asean5+** & $-528,253$ & & & & & & & 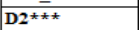 & $-180,105$ & & \\
\hline D2**** & 94,1919 & 0,72336 & & & & 0,67011 & 5,08 & & & 0,70991 & \\
\hline Tourisn & nvestment (II & sean5+) & & Tou & m Investment & (II_JPN) & & Tou & rism Investment & (IT_EU) & \\
\hline$\overline{D 1 * *}$ & 113053,8 & & 1,48 & Y_JPN*** & \begin{tabular}{l|}
0,596968 \\
\end{tabular} & & 0,87 & $\mathbf{Y}_{-} \mathbf{E U}+* * *$ & \begin{tabular}{|r|}
$-0,01105$ \\
\end{tabular} & 0,44376 & 3,39 \\
\hline & & & & & & & & R_EU*** & $-17,9038$ & & \\
\hline & & 0,25803 & & & & 0,17011 & & D1** & 188,7148 & & \\
\hline & CPI_Asean5+ & & & & CPI_JPN & & & & CPI_EU & & \\
\hline MS_Asean5+* & 0,267154 & & 4,35 & R_JPN* & $-1,45304$ & & 25,04 & R_EU $U^{* *}$ & $-1,60562$ & 0,98552 & 646,69 \\
\hline & & & & $\overline{\text { MS_JPN* }}$ & $-0,00071$ & 0,72493 & & $\overline{\text { MS_EU* }}$ & 0,017215 & & \\
\hline Total Consumpti & in Tourism Se & tor (C_Ase & $\mathrm{n5+)}$ & \begin{tabular}{|l} 
Total Consur \\
\end{tabular} & tion in Tourism & $\mathrm{m}$ Sector $(\mathrm{C}$ & JPN) & \begin{tabular}{|l|} 
Total Consum \\
\end{tabular} & ption in Tourism & a Sector EU & (C_EU) \\
\hline Y_Asean5+* & 0,701319 & & 13380,5 & Y_JPN* ${ }^{\star}$ & 84,15455 & & 105,22 & $\mathbf{Y}_{-} \mathbf{E U}^{*}$ & 0,709182 & & 5873,75 \\
\hline LC_Asean5+*** & $-0,05148$ & & & CPI_JPN $* * *$ & $-32,4295$ & & & LC_EU* & 0,117204 & & \\
\hline$\overline{\mathrm{Dl}^{* * *}}$ & 9,392831 & & & LC_JPN** & 0,332111 & & & $\mathrm{D1}^{* * *}$ & $-82,467$ & & \\
\hline & & 0,99968 & & D1*** & 130,0189 & 0,96118 & & & & 0,99928 & \\
\hline Government Expend & re for Tourism & Sector $\left(\mathbf{G}_{-}\right.$ & sean5+) & Government Expe & iture for Touris & ism Sector & Jepang) & Government Ex & penditure for Tou & urism Secto & $\mathbf{r}$ (G_EU) \\
\hline $\mathbf{Y}_{-}$Asean5+** & $-0,26128$ & & 1904,4 & LG_JPN ${ }^{* *}$ & 0,140256 & & 224,42 & $\mathbf{Y}_{\text {EU }}$ & $-0,39284$ & & \\
\hline$\overline{\text { LG_Asean5+* }}$ & 0,324774 & & & C_JPN* & 0,457655 & & & $\overline{-}$ & 0,992473 & & 521,25 \\
\hline C_Asean5+* & 0,632996 & 0,99777 & & DI** & 47,00178 & 0,98141 & & & & 0,9919 & \\
\hline Tour & n Export (X-Ase & an5+) & & & rism Export ( $\mathrm{X}$ & JPN) & & & Courism Export (X & $\left(\mathbf{X}_{-} \mathbf{E U}\right)$ & \\
\hline $\bar{Y}_{\text {_Asean5+* }}$ & 0,080062 & & 373,4 & LX_JPN* & 1,01398 & & 76,37 & Y_EU* ${ }^{*}$ & 0,003534 & & 688,52 \\
\hline$\overline{\mathbf{L X}} \_$Asean5+** & 0,529183 & & & $\overline{D 1}$ & $-8,7027$ & & & $\overline{\mathbf{L X}} \mathbf{E E U}^{*}$ & 0,713894 & & \\
\hline & & 0,98875 & & & & 0,94728 & & $\mathrm{Dl}^{* \star *}$ & $-3,64342$ & 0,99387 & \\
\hline Touri & a Import (M_As & ean5+) & & & ism Import (M & IJPN) & & & ourism Import ( & MEU) & \\
\hline $\mathbf{Y}_{-}$Asean5+t*t* & 0,059373 & & 226,43 & LM_JPN* & 0,963199 & & 42,64 & $\mathbf{Y}_{-} \mathbf{E U}^{*}$ & 0,002546 & 0,99238 & 553,3 \\
\hline LM_Asean5+* & 0,665885 & & & & & & & LM_EU* & 0,684027 & & \\
\hline D1**** & $-8,35661$ & 0,98158 & & D1 & $-7,95001$ & 0,90937 & & D1 ${ }^{* *}$ & $-3,29274$ & & \\
\hline & USA & & & & AUSTRALIA & & & & ROW & & \\
\hline Tour & m Arrival (TA & USA) & & & sm Arrival (T & A_AUS) & & Tou & irism Arrival (TA & A_ROW) & \\
\hline YC_USA & 3607,559 & 0,33969 & 1,65 & Y_Aus** & 731,474 & 0,70484 & & Y_ROW* ${ }^{*}$ & \begin{tabular}{|r|}
25397,15 \\
\end{tabular} & 0,93462 & \\
\hline PINA_USA & -252949 & & & PINA_AUS ** & -385998 & & & PIna_ROW* & $-2699,7$ & & \\
\hline$\overline{\text { Pop_USA }^{* \star}}$ & 11397,8 & & & Pop_Aus** & 744107,3 & & & Pop_ROW* & 126,1582 & & \\
\hline CPI USA & $-7490,61$ & & & & & & & & & & \\
\hline$\overline{\text { ER_USA }} A^{* \star * \star}$ & -119872 & & & CPI_Aus** & -50675 & & & CPI_ROW* ${ }^{*}$ & -23530 & & \\
\hline & & & & & & & 5,97 & & & & 35,74 \\
\hline Touris & Expenditture (T & E_USA) & & Touri & Expenditure & (IE_AUS) & & Touris & sm Expendditure ( & (IE_ROW) & \\
\hline$\overline{\text { YC_USA }^{*}}$ & 33,32132 & & 13,23 & YC_AUS** & 82,91908 & & & LTE_ROW* & \begin{tabular}{|l|l|}
0,97485 &
\end{tabular} & 0,97821 & 112,22 \\
\hline LTE_USA* & 0,465033 & & & PINA_AUS $* * *$ & $-709,678$ & & & & & & \\
\hline PINA_USA* & $-1538,55$ & & & ER_Aus & 949,3826 & & & 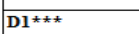 & $-14104,9$ & & \\
\hline ER USA A & $\begin{array}{l}-1030,29 \\
\end{array}$ & & & D2** & $-646,895$ & & & & & & \\
\hline$\overline{\text { D1**}}$ & \begin{tabular}{|l|}
$-173,733$ \\
\end{tabular} & 0,84107 & & & & 0,72704 & 6.66 & & & & \\
\hline Touri & Investment (II & (USA) & & Tour & m Investment & (II_AUS) & & Touri & ism Investment & (IT_ROW) & \\
\hline Intercept & 42,89489 & 0,22211 & 1,21 & Y_Aus** & \begin{tabular}{l|l}
0,011742 \\
\end{tabular} & & 2,16 & Y_ROW* ${ }^{*}$ & 228,1958 & 0,97202 & 147,63 \\
\hline$\overline{\mathbf{Y}_{-} \mathrm{USA} A^{* * *}}$ & 0,005309 & & & & & & & LIT_ROW* & 0,903415 & & \\
\hline R_USA $A^{\star \star \star \star}$ & $-14,0972$ & & & LIT_AUS $* * \star$ & $-0,34366$ & & & $\mathrm{Dl}^{*}$ & $-982,507$ & & \\
\hline LIT_USA $A^{* * *}$ & $-0,28897$ & & & & & 0.33663 & & & & & \\
\hline & CPI_USA & & & & CPI_AUS & & & & CPI_ROW & & \\
\hline$\overline{\text { MS_USA }^{*}}$ & 0,091821 & 0,83294 & 47,37 & R_Aus $* * *$ & $-3,05844$ & & 27,09 & MS_ROW & \begin{tabular}{l|l}
0,000076 \\
\end{tabular} & 0,61978 & 15,49 \\
\hline & & & & MS_Aus* & 0,367095 & 0,74037 & & & & & \\
\hline Total Consum & on in Tourism $\mathrm{S}$ & ector (C US & & Total Consur & tion in Tourism & $\mathrm{m}$ Sector $(\mathrm{C}$ & AUS) & Total Consun & ption in Tourism & n Sector (C & ROW) \\
\hline $\mathrm{Y}_{-} \mathrm{USA}^{*}$ & 0,408032 & & 7449,73 & $\mathbf{Y}_{\text {_Aus }}{ }^{\star}$ & 1,550863 & 0,99957 & 9834,25 & Y_ROW* ${ }^{*}$ & 660,0488 & 0,99046 & 441,41 \\
\hline LC_USA* & 0,651717 & & & CPI Aus** & 0,644418 & & & CPI ROW ROW $^{* * *}$ & 206,8445 & & \\
\hline D1* $^{*}$ & $-73,4465$ & & & LC_AUS** & 0,100138 & & & LC_ROW* & 0,891918 & & \\
\hline & & 0,99943 & & D1** & $-6,54855$ & & & D1* & $-1496,55$ & & \\
\hline Government Expe & iture in Touris & S Sector $(G$ & USA) & Government $E_{x}$ & diture in Tour & rism Sector & G AUS) & Governmer & $\begin{array}{l}\text { It Expenditure in } \\
\text { (G ROW) }\end{array}$ & Tourism S & ctor \\
\hline $\mathrm{Y}_{-} \mathrm{USA}^{*}$ & $-0,45065$ & & 1817,95 & Y_Aus ${ }^{* \star}$ & $-0,49661$ & 0,9982 & 2362,3 & Y_ROW ${ }^{* *}$ & $-108,964$ & 0,8912 & 34,81 \\
\hline LG USA* & 0,516773 & & & LG AUS** & 0,148019 & & & LG ROW* & 0,972479 & & \\
\hline $\mathrm{C}_{-} \mathrm{USA}^{*}$ & 0,752152 & & & C_Aus** & 0,710877 & & & C_ROW $* * *$ & 0,023466 & & \\
\hline D1** & 101,2839 & 0,99767 & & & & & & & & & \\
\hline & xport $\left(X_{2}\right.$ & SA) & & & sm Export & X-AUS) & & & sm Export $\mathbf{X}$ & X-Row) & \\
\hline$\overline{\mathbf{Y}_{-} \mathrm{USA}^{* *}}$ & 0,010368 & & 494,12 & Y_Aus ** & 0,047813 & 0,98213 & 233,58 & Y_ROW* ${ }^{*}$ & 455,2486 & 0,96906 & 133,13 \\
\hline $\mathrm{ER}_{\mathrm{U}} \mathrm{USA}^{* *}$ & 172,6296 & & & LX_AUS $* *$ & 0,490584 & & & LX_ROW* & 0,814811 & & \\
\hline LX_USA* & 0,759843 & 0,99147 & & & & & & D1 ${ }^{* \star}$ & $-1426,55$ & & \\
\hline & m Import (M & SA) & & & ism Import (M & I_AUS) & & & m Import (M & (_Row) & \\
\hline$\overline{\mathbf{Y}_{-} \mathrm{USA}^{*}}$ & 0,018025 & & 1053,79 & Y_Aus* & 0,09678 & & 1084,07 & Y_ROW* & 430,5336 & 0,96675 & 123,59 \\
\hline$\overline{\text { ER_USA }^{* *}}$ & 88,7776 & & & ER_Aus** & 3,761651 & & & LM_ROW* & 0,822421 & & \\
\hline LM_USA* ${ }^{*}$ & 0,466925 & 0,99598 & & $\mathrm{Dl}^{* *}$ & 1,213603 & 0,99609 & & $\mathrm{Dl}^{* \star}$ & \begin{tabular}{|l|}
$-1379,93$ \\
\end{tabular} & & \\
\hline
\end{tabular}


Analysis Determinants of Investment, Demand, and Supply Indonesian Tourism

\subsection{The Simulation Results}

\begin{tabular}{|c|c|c|c|c|c|c|c|}
\hline \multirow[t]{2}{*}{ Variable } & \multicolumn{7}{|c|}{ Change (\%) } \\
\hline & SIM1 & SIM2 & SIM3 & \begin{tabular}{|l|l} 
SIM4 & \\
\end{tabular} & SIM5 & SIM6 & SIM7 \\
\hline \multicolumn{8}{|l|}{ Asean5: } \\
\hline TA_Asean & 18,8 & 20,4 & $-98,5$ & 14,2 & 14,2 & $-172,4$ & $-32,949247$ \\
\hline TE_Asean & 6,03984064 & 6,03984064 & 6,03984064 & 6,03984064 & 6,03984064 & 6,03984064 & $-12,729185$ \\
\hline I_Asean & $-159,18396$ & $-163,5343$ & $-159,40864$ & $-159,40864$ & $-153,46771$ & $-159,40864$ & 0 \\
\hline CPI_Asean & $-0,0045869$ & $-0,5572601$ & $-89,00158$ & 0 & 0 & 0 & 0 \\
\hline C_asean & 1,31066242 & $-1,7003188$ & $-1,487779$ & 13,0534892 & $-1,6826072$ & $-1,6826072$ & 0 \\
\hline G_Asean & $-0,0577034$ & $-2,6543566$ & $-2,1927294$ & 27,813041 & $-2,5966532$ & $-2,5966532$ & 0 \\
\hline X_Asean & 5,23978686 & 3,46358792 & 3,46358792 & 3,46358792 & 3,46358792 & 3,46358792 & 0,68669528 \\
\hline M_Asean & 8,03571429 & 6,89935065 & 6,89935065 & 6,89935065 & 6,89935065 & 6,89935065 & 0,53151101 \\
\hline \multicolumn{8}{|l|}{ Jepang: } \\
\hline TA_JPN & $-2,0758203$ & $-2,9995682$ & 95,7458303 & $-2,0758203$ & $-2,0758203$ & $-11,86814$ & 0 \\
\hline TE_JPN & 20,3012287 & 20,3012287 & 20,3012287 & 20,3012287 & 20,3012287 & 20,3012287 & 3,18265683 \\
\hline I_JPN & 142,445642 & 139,518055 & 137,118795 & 137,118795 & 113,406915 & 137,118795 & 0 \\
\hline CPI_JPN & 0 & $-0,0840336$ & 10 & 0 & 0 & 0 & 0 \\
\hline C_JPN & $-3,7609174$ & $-6,3870239$ & $-17,960905$ & 7,53074684 & $-6,4939695$ & $-6,4939695$ & 0 \\
\hline G_JPN & $-7,8026634$ & $-10,738499$ & $-21,531477$ & 2,23970944 & $-10,835351$ & $-10,835351$ & 0 \\
\hline $\mathrm{X} \_\mathrm{JPN}$ & $-88,424979$ & $-88,357748$ & $-88,357748$ & $-88,357748$ & $-88,357748$ & $-88,357748$ & $-2,4061598$ \\
\hline M_JPN & 11,4566285 & 10,8837971 & 10,8837971 & 10,8837971 & 10,8837971 & 10,8837971 & 0,22140221 \\
\hline \multicolumn{8}{|l|}{ USA: } \\
\hline TA_USA & $-0,000646$ & $-2,1596584$ & $-85,287255$ & $-0,000646$ & $-0,000646$ & $-10,000452$ & $-11,147863$ \\
\hline TE_USA & $-10,642913$ & $-10,642913$ & $-10,642913$ & $-10,642913$ & $-10,642913$ & $-10,642913$ & $-10,910027$ \\
\hline IINA_USA & $-42,034423$ & $-99,963054$ & $-47,065212$ & $-47,065212$ & $-52,358962$ & $-99,947065$ & 0 \\
\hline CPI_USA & 0 & 0,28376844 & 10,045403 & 0 & 0 & 0 & 0 \\
\hline C_USA & 0,66595602 & $-0,8154115$ & $-2,5055771$ & 14,1125532 & $-0,7725529$ & $-0,7725529$ & 0 \\
\hline G_USA & $-0,0527108$ & 1,02911647 & $-1,87249$ & 26,6767068 & 1,10441767 & 1,10441767 & 0 \\
\hline XINA_USA & $-1,5656712$ & $-2,5224703$ & $-2,5224703$ & $-2,5224703$ & $-2,5224703$ & $-2,5224703$ & 7,37656157 \\
\hline M_USA & 2,51177394 & 0,23547881 & 0,23547881 & 0,23547881 & 0,23547881 & 0,23547881 & 5,01174628 \\
\hline \multicolumn{8}{|l|}{ Uni Eropa } \\
\hline TA_EU & 0,02894356 & 0,02894356 & 0,23154848 & 0 & 0 & $-9,985$ & 0 \\
\hline TE_EU & $-2,15554$ & $-2,15554$ & $-2,15554$ & $-2,15554$ & $-2,15554$ & $-2,15554$ & 1,85434662 \\
\hline I_EU & $-149,01382$ & $-149,55373$ & $-148,3558$ & $-148,34936$ & $-143,50767$ & $-148,34936$ & $\begin{array}{r}0 \\
\end{array}$ \\
\hline CPI_EU & 0 & $-0,3275109$ & 9,98908297 & 0 & 0 & 0 & 0 \\
\hline C_EU & 4,28273277 & 1,61214754 & 1,80488117 & 16,8615299 & 1,61960133 & 1,61960133 & 0 \\
\hline G_EU & 5,12446138 & 3,16762224 & 3,49880702 & 29,4238097 & 3,17830562 & 3,17830562 & 0 \\
\hline $\mathrm{X} E \mathrm{EU}$ & 11,0843983 & 9,4453583 & 9,4453583 & 9,4453583 & 9,4453583 & 9,4453583 & 0,19962695 \\
\hline M_EU & 14,4078771 & 12,54191 & 12,54191 & 12,54191 & 12,54191 & 12,54191 & 0,46635847 \\
\hline \multicolumn{8}{|l|}{ Autralia } \\
\hline TA_Aus & 13,7372178 & & & 11,9083267 & & 0,71741605 & \begin{tabular}{|r|}
0 \\
\end{tabular} \\
\hline TE_Aus & $-17,936775$ & $-17,936775$ & $-17,936775$ & $-17,936775$ & $-17,936775$ & $-17,936775$ & 12,0777892 \\
\hline I_AUS & 243,485021 & 215,668905 & 217,728376 & 236,72786 & 203,055672 & 236,72786 & 0 \\
\hline CPI_Aus & 0 & $-1,0093727$ & 9,94953136 & 0 & 0 & 0 & 0 \\
\hline C_Aus & 7,1372549 & 4,05882353 & 5,98039216 & 19,8627451 & 4,21568627 & 4,21568627 & 0 \\
\hline G_Aus & 7,79896014 & 5,02599653 & 8,01559792 & 29,8526863 & 5,28596187 & 5,28596187 & 0 \\
\hline $\mathrm{X}$ _Aus & 3,13116115 & 1,42679257 & 1,42679257 & 1,42679257 & 1,42679257 & 1,42679257 & 0,5776693 \\
\hline M_Aus & $-10,81104$ & $-14,084233$ & $-14,084233$ & $-14,084233$ & $-14,084233$ & $-14,084233$ & 2,11352434 \\
\hline \multicolumn{8}{|c|}{ Rest of The Worrld } \\
\hline TA_ROW & 2,36100744 & 0,50308762 & 0,50308762 & 0,40666745 & 0,40666745 & $-9,6340983$ & 0 \\
\hline TE_ROW & 2,64595713 & 2,64595713 & 2,64595713 & 2,64595713 & 2,64595713 & 2,64595713 & 0,17266218 \\
\hline I_ROW & 3,92100131 & 3,19338177 & 3,18480893 & 2,97048801 & $-7,3265608$ & 2,97048801 & 0 \\
\hline CPI_ROW & 1,12089376 & $-0,3773306$ & 10,0066588 & 0,00554898 & 0,00554898 & 0,00554898 & 0 \\
\hline C_ROW & 2,27604172 & 1,4016984 & 1,79092869 & 16,62828 & 1,41611434 & 1,41611434 & 0 \\
\hline G_ROW & $-3,6637055$ & $-3,6520931$ & $-1,3992916$ & 4,62753295 & $-1,5560588$ & $-1,5560588$ & 0 \\
\hline $\mathrm{X} \_$ROW & 5,2810965 & 3,66806099 & 3,66806099 & 3,66806099 & 3,66806099 & 3,66806099 & $-0,3762439$ \\
\hline M_ROW & 5,15410467 & 3,60518836 & 3,60518836 & 3,60518836 & 3,60518836 & 3,60518836 & $-0,3744247$ \\
\hline \multicolumn{8}{|l|}{ Penawaran } \\
\hline CT_Ina & 0,00162322 & $-0,0253032$ & 0,10006684 & 0,001632 & 0,001278 & 0 & $-0,477236$ \\
\hline IT_Ina & 0,00731687 & $-0,0999999$ & 0 & 0,006872 & 0,010487 & 0 & 0,00011629 \\
\hline GT-Ina & 0,000172 & 0,000173 & 0,100008 & 0,001223 & $-0,001742$ & 0 & 0,00017252 \\
\hline
\end{tabular}




\section{Conclusions And Policy Implications}

1. Factors affecting investment ( inward) and the Indonesian tourism trade is the population of the country of origin of tourists, the distance between origin countries of foreign tourists to Indonesia , Indonesia's economic growth , the economic growth of the country of origin of tourists, Indonesian tourism prices, the exchange rate , the export value of tourism previous year, and the value of imports of tourism in the previous year with an average level of influence of these variables on the amount of investment and the value of trade (exports and imports ) tourism amounted to 95 percent, which indicates that the explanatory variables in the empirical study is greatly to the development of the tourism trade and investment flows, while the remaining 5 percent is influenced by other factors such as factors beyond the research promotion, tourism prices from other countries ( competitors ), market potential ( market share ).

2.Dampak tourism investment flows towards tourism demand is empirically known only by 42 percent, which means that as long as the investments made by both the government, private, and foreign influences have produced a significant amount of demand for Indonesian tourism. While the contribution of tourism to supply tourism investment in Indonesia is empirically known by 96 percent, which means that the influence of tourism investment on very large amount of tourism supplys .

3 . Economic growth that a country ( country of origin of tourists) the number of foreign tourists visiting Indonesia tends to increase, while when economic growth occurs in the number of foreign tourists visiting Indonesia tends to decrease, this is because in times of economic growth in Indonesia increased commodity prices , including the price - tourism commodity prices will be more expensive than the previous

4 . Rupiah exchange rate against foreign currencies also affect the tourism price changes, so does the Indonesian consumer price index and the consumer price index Country of origin of tourists also affects the price of tourism in the country. Strengthening of the rupiah against foreign currencies would reduce the country of origin of tourists spending foreign tourists and foreign tourists while in Indonesia.

5 . Qualitative factors such as the economic crisis and travel warning travelers do not always affect the intention to visit Indonesia, as well as the intention of potential investors to invest in Indonesia him in the tourism sector especially from ASEAN ( Singapore, Malaysia ), Japan , and South Korea as the Bali Bombing I and II .

6 . Increased demand for, and supply of tourism have not been able to reduce the negative effects on the agricultural sector as a result of the liberalization trend in the tourism sector

\section{Acknowledgment}

Based on the conslucion, some advices given as follow:

1 . Because of the large capacity of Indonesia's tourism sector to the national economy ( based on BPS data for 13.9 percent of total GDP in 2012 ) while the contribution of tourism is only about 6 per cent in the same year, the Indonesian tourism investment needs to be increased back the number and value of investments in the sector tourism ( considering the potential of natural and cultural, as well as the availability of adequate resources to support the growth of tourism ) .

2 . Investment to tourism supply of a state / regional tourist destination is generally done in order to improve the capacity and competitiveness of tourism itself, so that the available resources in a tourist area has added value, as well as the potential of a tourist area if it is supported by the large quality and quantity of investment made , in this case the role of government, private, and foreign indispensable. Given the conditions have not been optimal investment made in eastern Indonesia and other regions in Indonesia, it would require the development of appropriate investment strategy to attract investors, both domestic and foreign, one of them by providing facilities for the investors as profit returns ( discount rate) are sufficiently attractive to potential investors , investment promotion intensively conducted by foreign governments, the Act and the regulations supporting the investment climate and investment certainty, housekeeping services system administration services such as licensing, tax services, reform the banking system and international payments sufficient, tax incentives for investors such as tourism tax holiday, tax allowance and product subsidies, facilities and supporting infrastructure such as adequate tourism ports, airports, terminals, roads, bridges, and others.

3 . The impact of economic growth both individually and simultaneously should pay attention to and consider their impact on the various sectors of the economy . Lack of consistent data on sectoral budgets in particular tourism and other sectors related to the impact of fiscal policy making sector becomes the focus, besides the preparation of special tourism sector analysis of data such as Input - Output tables tourism .

4. The role of fiscal policy in particular government expenditure is still very dominant in influencing the economy so the need for improvement of fiscal policy in the future . So is the policy of increased investment especially in infrastructure is needed to support the growth of tourism . Besides, the government also should be able to make a well-planned program planning and careful investment in the development of tourism in particular, to be coordinated and integrated with other sectors since tourism is a sector that provides significant multiplier effect on the development of other sectors . 
7 . The Increasing of investment and tourism trade has not been able to bring the desired level of prosperity for the local community , therefore in an effort to increase investment and trade tourism needs government attention to the negative impacts of tourism development to local communities through policies and pro -poor local communities meibatkan to people not just be a spectator in the popularity of liberalization and economic growth in tourism.

\section{References}

[1]. Alguacil, Ma. Teresa \& Cuadros, Ana \& Orts, Vicente, 2002.Foreign Direct Investment, Exports and Domestik Performance in Mexico: a Causality Analysis,. Economics Letters, Elsevier, vol. 77(3), pages 371-376, November.

[2]. Anderson, James E. 1979. A Theoretical Foundation For The Gravity Equation, American Economic Review 69, $106-116$

[3]. Antariksa B. 2010. Pengaruh Liberalisasi Perdagangan Jasa terhadap Daya Saing Kepariwisataan Indonesia. Prosiding Pertemuan Diklat Pariwisata tingkat Lanjutan Tahun 2010; Jakarta, 29 Juli 2010. Jakarta: Pusdiklat Kemenbudpar.

[4]. Antara, Made. 1999. Dampak Pengeluaran Pemerintah dan Wisatawan terhadap Kinerja Perekonomian Bali: Pendekatan Sosial Accounting Matrix. (Disertasi). Bogor: IPB

[5]. Archer, Brian \& Cooper. 1994. The Positive and Negatif Impacts of Tourism. Oxford: Butterworth-Heinemann.

[6]. Barudin. 2011. Dampak Liberalisasi Perdagangan dan Peningkatan Permintaan Pariwisata terhadap Kinerja Ekonomi Makro dan Sektoral di Indonesia. (Thesis). Bogor: IPB

[7]. Choyakh H. 2008. Modeling Tourism Demand in Tunisia Using Cointegration and Error Correction Models. London: PhysicaVerlag.

[8]. Clarida, Richard \& Gali, Jordi \& Gertler, Mark, 2002. A Simple Framework for International Monetary Policy Analysis. Journal of Monetary Economics, Elsevier, vol. 49(5), pages 879-904, July.

[9]. Darmoyo J. 2003. Analisis Potensi Kecenderungan (Trend) Wisatawan Jepang terhadap Minat Obyek Wisata.. JIKP, Volume 4 April 2003.

[10]. Deardoff, Alan. 1998. Determinants of Bilateral Trade: Does Gravity Works in a Neo Classical World?. National Bureau Economic Research. Working Paper no. 5377. In The Regionalization of the World Economy, University of Chicago Press

[11]. Deliarnov,1995. Pengantar Ekonomi Makro. Jakarta: UI- Press

[12]. Djamaluddin, Idham. 2006. Aplikasi Gravity Model Dalam Estimsi Permintaan Jasa Pariwisata ASEAN. Thesis Universitas Indonesia. Depok. Universitas Indonesia

[13]. Dornbusch, R., S. Fischer, dan R. Startz. 2004. Macroeconomics. 9th edition. McGraw-Hill, Boston

[14]. Dunning, John H. 1980. Towards an Eclectic Theory of International Production: Some Empirical Tests. Reading University. England

[15]. Durbarry, Ramesh. 2006. Tourism Expenditure in UK: Analysis of Competitiveness Using Gravity Based Model. Nothingham University Business School. England

[16]. Gujarati, D. 1995. Basic Econometrics. Third Edition. McGraw-Hill, New York

[17]. Goeldner, C. R., J. R. B. Ritchie and R. W. McIntosh. 2000. Tourism Components and Supply. In Tourism: Principles, Practices, Philosophies. New York, John Wiley and Sons Ltd.: 362-393

[18]. Greene. 2000, Econometric Analysis. 4th ed., Englewood Cliffs, NJ: Prentice-Hall

[19]. Hady H. 2004. Ekonomi Internasional, Teori dan Kebijakan Perdagangan Internasional. Buku kesatu. Jakarta : Ghalia Indonesia.

[20]. Hanafiah, M.H. \& Harun, M.F. 2011. Trade and Tourism Demand: A case of Malaysia. International Conference on Business and Eonomic Research. Malaysia

[21]. Heriawan R. 2004. Peranan dan Dampak Pariwisata pada Perekonomi Indonesia: Suatu Pendekatan Model I-O san SAM [Disertasi]. Bogor: IPB.

[22]. Horváth E, Frechtling DC. 1999. Estimating the Multiplier Effects of Tourism Expenditures on a Lokal Economy through a Regional Input-Output Model. Journal of Traveo Researchvol. 37, no. 4 May 1999. hlm 324- 332.

[23]. Intriligator, M.R. Bodkin and C. Hsiao. 1978. Econometrics Models, Techniques and Application. Prentice-Hall Inc., New Jersey

[24]. Ishikawa. Jota \& Horiuchi Eiji, 2012. Strategic Foreign Direct Investment in Vertically Related Markets. Discussion papers 12014, Research Institute of Economy, Trade and Industry (RIETI).

[25]. Koutsoyianis, A. 1977. Theory of Econometrics: An Introductory Exposition of Econometric Methods. Second Edition. The Macmillan Publisher Ltd,. London

[26]. Krugman P, Maurice O. 2004. Economi Internasional: Teori dan Kebijakan. Edisi Kelima. Jilid I. Jakarta: Raja Grafindo Persada.

[27]. Paul R. Krugman \& Mauricen Stfeld, International Economics, Theory and Practics, London Scott, Foresman \& Company, 1997

[28]. Kweka J. 2004. Tourism and The Economiy of Tanzania: a CGE Analysis. Research Fellow Economic and Sosial Research Foundation. Oxford, UK: P.0. BOX 31226., 21 - 22 March 2004.

[29]. Linneman, H. (1966). An Econometric Study of International Trade Flows. North-Holland. Amsterdam

[30]. Lumaksono, Adi. 2011. Dampak Ekonomi Pariwisata Internasional Pada Perekonomian Indonesia: Suatu Pendekatan Ekonometrika dan Analisis Input-Output (Disertasi). IPB. Bogor

[31]. Mankiw, N.G., D. Romer, dan D. Weil. 2002. A Contribution to the Empirics of Economic Growth, Quarterly Journal of Economics

[32]. Mankiw, N.G. 2004. Macroeconomics. Harvard University. Worth Publisher Inc.

[33]. Marpaung, Happy. 2002. Pengantar Pariwisata. Bandung : Alfabeta

[34]. Mathieson, Alister dan Wall, Geofrey, 1982, Tourism: Economic, Physical, and Sosiallmpacts, Longman, London and New York

[35]. Mason, P. 2003, Tourism Impacts, Planning and Management . Oxford

[36]. Millberg, William. 1999. Foreign Direct Investment and Development: Reassessing the Costs and Benefits. International Monetary and Financial Issues for the 1990's, Vol. VII, UNCTAD: Geneva

[37]. Nicholson W. 2005. Microeconomic Theory, Basic Principles and Extensions. Ninth Edition. Canada: Thomson South-western.

[38]. Oktaviani R. 2008. Model Ekonomi Keseimbangan Umum: teori dan aplikasinya di Indonesia. Bogor: Departemen Ilmu Ekonomi FEM, IPB.

[39]. Oktaviani R, Novianti T. 2009. Teori Perdagangan Internasional dan Aplikasinya di Indonesia. Bagian I. Bogor: Departemen Ilmu Ekonomi FEM, IPB.

[40]. Peter H. Lindert, Thomas A. Pugel. International economis, Edition, 10, illustrated. Publisher, Irwin,1996.

[41]. Pitana, I Gde, \& Gayatri, Putu G. 2005. Sosiologi Pariwisata. Yogyakarta.: Andi

[42]. Pramadhani, M., Bissoondeeal R., \& Driffield, N. (2007). FDI, Trade and Growth, a Causality Link. Research Paper, Aston Business School. Aston University, Birmingham RP 0710.

[43]. Pyndick, R.S. and D.L. Rubinfeld. 1991. Econometric Models and Economic Forecast. Third Edition. Mc Graw-Hill Inc, Singapore 
[44]. Rahayu, Ani Sri, 2010, Fiscal Policy, Bumi Aksara, Jakarta

[45]. Raharja, Prathama, dan Manurung. 2008. Pengantar Ilmu Ekonomi. Lembaga Penerbit Fakultas Ekonomi Universitas Indonesia. Jakarta

[46]. Ratnawati A. 1995. Dampak Kebijakan Penurunan Tarif Impor dan Pajak Ekspor: Kinerja Perekonomian Sektor Pertanian dan Distribusi Pendapatan di Indonesia [Disertation]. Bogor: IPB.

[47]. Ridwan. 2010. Analisis Aliran Perdagangan dan Investasi Dalam IntegrasiEkonomi Asean: Pendekatan Model Gravity (Disertasi). IPB.Bogor

[48]. Riyadi, D.S. 1998. Peranan arus masuk investasi asing langsung (FDI) Inflow Terhadap Pertumbuhan Eonomi Indonesia. Tesis master yang tidak dipublikasikan. Institut Teknologi Bandung, Bandung

[49]. Romer, Paul, M. 1986. The Journal of Political Economy, Volume 94 Vol 5. Pp 1002-1037

[50]. Sadoulet E, de Janvry A. 1995. Quantitative Development Policy Analysis. Baltimore: The Johns Hopkins University Press.

[51]. Samuelson. P.A., and Nordhaus. 2004. Economics. $17^{\text {th }}$ Edition. Irwin-Mc Graw Hill

[52]. Salvatore D. 1996. Ekonomi Internasional. Munandar H, penerjemah; Sumiharti Y, editor. Jakarta: Erlangga. Terjemahan dari: International Economics.

[53]. Sanso, Marcos, et al, 199), Bilteral Trade Flows, The Gravity Equation and Functional Form, Vol. 75 No. 2

[54]. Sinclair, M. T., and C. M. S. Sutcliffe. 1988. The Estimation of Keynesian Income Multipliers at The Sub-national level. Applied Economics 20(11), 1435-1444.

[55]. Smith, S. L. J. 1988. Defining Tourism: A Supply-Side View. Annuals of Tourism Research 15(2):179-190.

[56]. Spillane \& James, J. 1994. Tourism Economics: History and Prospects. Kanisius. Yogyakarta

[57]. Sugiyarto G, Blake A, Sinclair MT. 2003. Economic Impact of Tourism and Globalisation in Indonesia. Annuals of Tourism Research, 30 (3). Hlm 683-701.

[58]. Sukirno, Sadono. 2001. Microekonomi. Edisis ke-2. Jakarta. Rajawali Pess

[59]. Suyana, Made. 2006. Pengaruh Perkembangan Pariwisata Terhadap Kinerja Perekonomian dan Perubahan Struktur Ekonomi Serta Kesejahteraan Masyrakat di Provinsi Bali (Disertasi). Universitas Airlangga. Surabaya

[60]. Tambunan T. 2004. Globalisasi dan Perdagangan Internasional. Jakarta: Galia.

[61]. Tantowi A. 2009. Determinants of Tourism Demand in Indonesia: A Panel Data Analsys [Tesis]. Yokohoma, Jepang: Yokohama National University.

[62]. Thapa, K. (2005). Challenges and Opprtunities of Village Tourism in Sirubari. B.Sc Thesis, School of Environmental Management and Sustainable Development, Pokhara University, Kathmandu

[63]. UNWTO 2009. Tourism Highlights 2009 Edition . http://www.unwto.org [21 April 2010].

[64]. UNWTO. 2011. Tourism Highlights 2011 Edition. http://www.unwto.org [2 November 2011].

[65]. Utami, Diyah. 2007. Analisis Pengaruh Pengeluaran Rutin dan Pengeluaran Pembangunan Pemerintah terhadap Pertumbuhan Ekonomi di Indonesia Periode 1975-2004 (Thesis). IPB. Bogor

[66]. Uysal, M.and Crompton, J.L., 1984. Demand for international tourist flows to Turkey, Tourism Management.

[67]. Wagner JE. 1997. Estimating the Economic Impacts of Tourism. Annuals of Tourism Research 24 . hlm 592-608.

[68]. Widjaja A. 2000. Dampak Liberalisasi Perdagangan terhadap Kinerja Ekonomi Indonesia: Suatu Pendekatan Makroekonometrika [Disertation]. Bogor: IPB.

[69]. World Economic Forum. 2011. The Travel \& Tourism Competitiveness Report 2011. Geneva, Switzerland.

[70]. Yoety, Oka. 1996. Tourism Marketing. Bandung : Angkasa.

[71]. http://beritadaerah.com/2013-04-08/perhotelan-tekankan-efisiensi-energi-hadapi-kenaikan-tdl 